\title{
Bacterial diversity of epilithic biofilm assemblages of an anthropised river section, assessed by DGGE analysis of a 16S rDNA fragment
}

\author{
Emilie Lyautey ${ }^{1}$, Samuel Teissier ${ }^{1}$, Jean-Yves Charcosset ${ }^{2}$, Jean-Luc Rols ${ }^{1}$, \\ Frédéric Garabétian ${ }^{1, *}$ \\ ${ }^{1}$ Laboratoire d'Ecologie des Hydrosystèmes, UMR 5177 CNRS-Université Paul Sabatier, 118 route de Narbonne, \\ 31062 Toulouse cedex 04, France \\ ${ }^{2}$ Laboratoire ‘Dynamique de la Biodiversité', UMR 5172 CNRS-Université Paul Sabatier, 29 rue J. Marvig, \\ 31055 Toulouse cedex 04, France
}

\begin{abstract}
PCR-DGGE analysis of a 16S rDNA fragment was used to determine spatial patterns of epilithic bacteria diversity over a $100 \mathrm{~km}$ river section. Epilithic biofilms were collected on natural substrata in a river reach (mid-slope of the river Garonne) where changes in epilithic bacterial activities and densities were expected due to the presence of a major urban centre (Toulouse city). Nitrogen and phosphorus forms increased 2- to 10-fold downstream of this urban centre. Close values of biomass (18 to $27 \mathrm{~g} \mathrm{~m}^{-2}$ in 2000 and 10 to $16 \mathrm{~g} \mathrm{~m}^{-2}$ in 2001), bacterial densities (3 to $11 \times 10^{12}$ cells $\mathrm{m}^{-2}$ for total bacteria) and activities (3.6 $\mathrm{mg} \mathrm{N} \mathrm{m}^{-2} \mathrm{~h}^{-1}$ for nitrification and 0.3 to $1.1 \mathrm{mg} \mathrm{N} \mathrm{m}^{-2} \mathrm{~h}^{-1}$ for denitrification) were recorded at the different sampling sites. Conversely, in regard to community composition, up- and downstream samples were discriminated between according to their banding patterns: $>60 \%$ similarity within clusters versus $<45 \%$ similarity between clusters as calculated with the Jaccard similarity index. Up- and downstream samples shared 50 of the 74 detected bands, the maximum number of bands being 45 for 1 sample. Derived from relative intensities, Simpson (ca. 0.034) and Shannon (ca. 5.06) diversity indices indicated diversified communities. For all of the tested samples, specific richness and diversity indices exhibited relatively homogeneous values, suggesting that there may be a similar level of diversity in biofilms from contrasting sources.
\end{abstract}

KEY WORDS: Biofilms · Bacterial diversity · DGGE fingerprinting · River Garonne Resale or republication not permitted without written consent of the publisher

\section{INTRODUCTION}

To assess bacterial community dynamics in aquatic environments, most studies of global bacterial diversity have focused on planktonic communities (Murray et al. 1996, Øvreås et al. 1997, Casamayor et al. 2000, Schauer et al. 2000). In running waters, other typical microbial assemblages are biofilms colonising pebbles in so-called gravel bed rivers (Biggs 1995).

Such river epilithic biofilms are complex microbial communities composed of algae, bacteria and other micro-organisms (Lock 1993). Algae account for more than $30 \%$ of total biomass (Peterson 1996) and were shown to control either biomass (Sobczak 1996) or diversity (Jackson et al. 2001) of bacteria by providing organic nutrients and physical habitats.

For benthic algal communities, it was observed that a source of trophic effluents causes a modification of community structure, without affecting richness and diversity or even biomass as measured by chlorophyll a (chl a) levels (Stelzer \& Lamberti 2001, Griffith et al. 2002). On the other hand, Montuelle et al. (1996) have reported changes in Nitrobacter serotypes associated with wastewater treatment plant discharge, suggesting that such external factors may also affect epilithic bacterial communities. Community patterns of natural 
epilithic bacteria may thus result both from autogenic succession and from external factors affecting predominantly spatial variation.

Only 3 studies on epilithic bacterial diversity in freshwater systems have been carried out: (1) Brümmer et al. (2000) have detailed the main phylogenetic groups of epilithic communities in 2 rivers of different trophic levels using fluorescence in situ hybridisation (FISH); (2) Jackson et al. (2001) have focused on the mechanisms of succession during colonisation using the PCR-DGGE; and (3) Araya et al. (2003) have detailed the bacterial composition of epilithic communities using both methods. Applied to the study of bacterial diversity, PCR-DGGE is a cultivation-independent technique based on the study of a 16S rDNA fragment (Muyzer et al. 1993), which provides rapid assessment along with relevant comparison of diversity patterns.

In the present work, we used the latter fingerprinting method to study spatial patterns of epilithic bacterial communities over a $100 \mathrm{~km}$ river section. Concerning bacterial diversity, a realistic view of the actual diversity was expected from sampling natural substrata (pebbles) as artificial substrata are known to affect algal diversity (Cattaneo \& Amireault 1992). In regard to spatial patterns at the river reach scale, we intended to analyse the similarity of bacterial assemblages in a system including identified sources of spatial changes in communities (Teissier et al. 2002).

\section{MATERIALS AND METHODS}

Study sites. Sites are located on the mid-slope of the river Garonne (mean flow: $600 \mathrm{~m}^{3} \mathrm{~s}^{-1}$ ), which corresponds to a 6th-order shallow river. During low-water periods, current velocities on the river bottom $(<1 \mathrm{~m}$ $\left.\mathrm{s}^{-1}\right)$ and mean depths $(<1 \mathrm{~m})$ enable the development of an important epilithic biomass. Six sites were studied up- and downstream of Toulouse city, whose distances from the main wastewater treatment plant (550000 equivalent inhabitants) are respectively: Aouach (U1): $-36 \mathrm{~km}$; Pinsaguel (U2): $-12 \mathrm{~km}$; Fenouillet (D1): 6 km; Gagnac (D2): 12 km; Bourret (D3): $37 \mathrm{~km}$; and Verdun (D4): $55 \mathrm{~km}$. U1 and U2 are the upstream reference sites, D1 is located at the complete mixing point of the river waters with Toulouse main wastewater treatment plant discharge and D2 is located at the suburbs boundaries. Note that the years of sampling are indicated in subscript, e.g. D2 $2_{00}$ indicates a sample collected at the second site downstream, Gagnac, in 2000.

Water chemistry. Water samples were collected at the different sites in order to assess nitrogen and phosphorus concentrations. Nitrogen forms were measured according to Rodier (1996) and phosphorus forms were quantified according to Motomizu et al. (1983).

Sampling procedures. Sampling was performed in September 2000 and 2001. For each sampling date, all sites were sampled, except in 2000, where no sample was taken from U1. Nine pebbles (mean diameter: $12 \mathrm{~cm}$ ) from 3 distinct depths of a transect of the riffle $(30,50$ and $70 \mathrm{~cm})$ were sampled and kept in sterile bags at $4^{\circ} \mathrm{C}$. Within $6 \mathrm{~h}$ following the sampling procedure, biofilm was removed from the upper surface with a toothbrush (treated with $\mathrm{NaOH} 1 \mathrm{~N}$ to remove all trace of DNA) and suspended in filtered water $(0.2 \mu \mathrm{m})$. The scrubbed surface of the pebbles was traced on tracing paper and its area $\left(\mathrm{m}^{2}\right)$ calculated from the mass of the tracings. Except for biomass and activities, all measurements are performed using a mixed suspension from the 9 pebbles biofilms.

Measurement of biomass. For each depth, a $50 \mathrm{ml}$ aliquot of biofilm suspension (about $5 \mathrm{~g}$ dry mass) was centrifuged $(2300 \times g, 20 \mathrm{~min}$, SIGMA-202). Dry mass was determined by weighing the dry pellet $\left(80^{\circ} \mathrm{C}\right.$, overnight). This pellet was then combusted $\left(500^{\circ} \mathrm{C}\right.$, overnight) for the determination of the ash-free dry mass (AFDM).

Nitrification and denitrification rates. The activity measurements were performed in situ in benthic chambers for 2001 samples from U1, D2 and D3 according to Teissier \& Torre (2002).

Numeration of nitrifying bacteria. Microvolume most probable number (MPN) numerations of $\mathrm{NH}_{4}{ }^{+}-$ oxidising bacteria for each site were performed according to Teissier et al. (2002) using the medium recommended by Schmidt \& Belser (1994).

Faecal coliforms. Appropriate dilutions of homogenised biofilm suspension were inoculated on TTC-tergitol 7 medium (Biokar Diagnostics) and incubated between 18 and $24 \mathrm{~h}$ at $44^{\circ} \mathrm{C}$. Typical colonies (yellow or orange colonies surrounded by a yellow halo) were counted as characteristics of coliforms and expressed as colony-forming units ( $\mathrm{CFU}$ ).

Bacterial densities. In 2000, the total bacterial densities were measured according to Porter \& Feig (1980) using DAPI staining. In 2001, bacteria were counted after staining with a LIVE/DEAD BacLight bacterial viability kit (Molecular Probes) according to Boulos et al. (1999). Counting was carried out on a Leitz Dialux 22 microscope $(1250 \times$ magnification) fitted for epifluorescence: HBO (Halogen Photo Optic, Osram) $100 \mathrm{~W}$ mercury light source, with an excitation filter for 270 to 380 and 450 to $490 \mathrm{~nm}$, and a barrier filter of 410 to $580 \mathrm{~nm}$ and a $515 \mathrm{~nm}$ cut-off filter for DAPI and LIVE/DEAD BacLight, respectively.

A linear relationship $(y=1.045 x)$ was found between LIVE/DEAD BacLight and DAPI staining $\left(\mathrm{R}^{2}=0.997\right.$; $\mathrm{n}=16$ ). 
DNA extraction and purification. DNA extraction was carried out according to Dumestre et al. (2001). Briefly, $10 \mathrm{ml}$ of the biofilm suspension were centrifuged $\left(1500 \times g, 45 \mathrm{~min}, 4^{\circ} \mathrm{C}\right.$, Jouan $\left.\mathrm{K}-63 \mathrm{~F}\right)$ and the supernatant was discarded. Then $1 \mathrm{ml}$ of lysis buffer (40 mM EDTA, $50 \mathrm{mM}$ Tris- $\mathrm{HCl} \mathrm{pH} 8.3,0.75 \mathrm{M}$ sucrose) was added to the pellet for storage at $-70^{\circ} \mathrm{C}$. Biofilm material was incubated with lysozyme $(1 \mathrm{mg}$ $\mathrm{l}^{-1}$ ) for $45 \mathrm{~min}$ at $37^{\circ} \mathrm{C}$ and then with Proteinase $\mathrm{K}$ $\left(0.2 \mathrm{mg} \mathrm{l}^{-1}\right)$ and $\operatorname{SDS}(1 \%)$ for $1 \mathrm{~h}$ at $55^{\circ} \mathrm{C}$. DNA was extracted with phenol:chloroform:isoamyl-alcohol (25:24:1) and chloroform:isoamyl-alcohol (24:1). The aqueous phase was concentrated using a microconcentrator (Amicon, Centricon 100, 100000 Da cut-off) to remove humic acids. After extraction, DNA concentration was determined by fluorimetry using the DNA Quantitation Kit Fluorescence Assay (Sigma, DNAQF).

PCR. The variable regions V3 to V5 were amplified using the following primers (Genset): 341F (5'-CCT ACG GGA GGC AGC AG-3') with a 40 bp GC sequence clamped to its $5^{\prime}$ end $\left(5^{\prime}\right.$-CGC CCG CCG CGC CCC GCG CCC GTC CCG CCG CCC CCG CCC G-3') and 907R (5'-CCG TCA ATT CMT TTG AGT TT-3'). This set of primers was designed to be specific for most bacteria (Muyzer et al. 1997). The reaction mixture $(50 \mu \mathrm{l})$ contained $50 \mathrm{ng}$ microbial DNA, $200 \mu \mathrm{M}$ of each deoxynucleoside triphosphate, $0.48 \mu \mathrm{M}$ of each of the primers, $2.5 \mathrm{mM} \mathrm{MgCl}_{2}, 75 \mathrm{mM}$ Tris- $\mathrm{HCl}$ (pH 8.0), $3 \mathrm{mg} \mathrm{ml}^{-1} \mathrm{BSA}$ and $2.5 \mathrm{U}$ DNA polymerase (Goldstar). The PCR was performed with a T3 thermocycler (Biometra) using a programme described elsewhere (Schauer et al. 2000). PCR products were quantified by agarose gel electrophoresis using Molecular Mass Ruler (BioRad).

DGGE. Vertical DGGE was performed using a DCode Universal Mutation Detection System (BioRad) as described by Muyzer et al. (1997). The gel contained a gradient of denaturant ranging from 35 to $70 \%$ (100\% denaturant is $7 \mathrm{M}$ urea and $40 \%$ deionised formamide). DGGE was run at $100 \mathrm{~V}$ for $18 \mathrm{~h}$ at $60^{\circ} \mathrm{C}$. After electrophoresis, the gel was stained with $2 \times$ SYBR Green I (Sigma) and visualised by UV transillumination. The gel image was captured using a CCD camera and Biocapt software (Vilber Lourmat). Image analysis was done using Bio-1D++ software (Vilber Lourmat), which allows fragment detection and quantification. For each sample, a densitometric profile was generated to determine the relative contribution of each band to the total signal in the sample lane.

Similitude and dendrogram construction. Amplified bands were scored as present or absent. A triangular matrix was constructed from the Jaccard similarity index $\mathrm{J}=[c /(a+b-c)] \times 100$, where $a$ is the number of bands of Sample A, $b$ the number of bands of Sample
$B$ and $C$ the number of bands that are in common to Samples A and B (Jaccard 1908). A dendrogram was constructed using the unweighted pair-group method of arithmetic averages (UPGMA) (Michener \& Sokal 1957).

Diversity indexes. The values of relative intensity of each band were used to calculate the Shannon $\left(H^{\prime}\right)$ and Simpson $(D)$ diversity indices:

$$
H^{\prime}=-\sum_{i=1}^{i=\mathrm{n}} p i \ln p i \quad D=\sum_{i=1}^{i=\mathrm{n}} p i^{2}
$$

where $\mathrm{n}$ is the number of bands in the sample and $p i$ the relative intensity of the $i$ th band (Simpson 1949, Shannon \& Weaver 1963).

\section{RESULTS}

\section{Water chemistry and quality}

Differences in water quality were recorded up- and downstream of Toulouse. In 2001, the mean concentrations, taken over $12 \mathrm{wk}$ before biofilm sampling, of the different forms of nitrogen and phosphorus were about 2- to 10-fold higher at D2 than at U1 (Table 1).

\section{Parameters of the biofilms}

In both 2000 and 2001, biofilms exhibited similar values of AFDM ranging from 18 to $27 \mathrm{~g} \mathrm{~m}^{-2}$ in 2000

Table 1. Concentrations $\left(\mathrm{mg} \mathrm{l}^{-1}\right.$; mean $\left.\pm \mathrm{SE}\right)$ of nitrogen and phosphorus forms at 2 sites (U1 and D2) in the river Garonne during the 12 wk before biofilm sampling in 2001

\begin{tabular}{|lcc|}
\hline & $\mathrm{U} 1$ & $\mathrm{D} 2$ \\
\hline $\mathrm{NH}_{4}{ }^{+}-\mathrm{N}$ & $0.029 \pm 0.008$ & $0.252 \pm 0.079$ \\
$\mathrm{NO}_{2}{ }^{-}-\mathrm{N}$ & $0.020 \pm 0.005$ & $0.119 \pm 0.034$ \\
$\mathrm{NO}_{3}{ }^{-}-\mathrm{N}$ & $0.737 \pm 0.024$ & $1.642 \pm 0.097$ \\
$\mathrm{PO}_{4}{ }^{3-}-\mathrm{P}$ & $0.009 \pm 0.001$ & $0.093 \pm 0.008$ \\
Total P & $0.030 \pm 0.003$ & $0.123 \pm 0.007$ \\
\hline
\end{tabular}

Table 2. Ash-free dry mass (AFDM $\pm \mathrm{SE}$ ) and bacterial densities of epilithic biofilms collected in 2000

\begin{tabular}{|llc|}
\hline Site & $\begin{array}{c}\text { AFDM } \\
\left(\mathrm{g} \mathrm{m}^{-2}\right)\end{array}$ & $\begin{array}{c}\text { Bacterial densities } \\
\left(10^{12} \text { cells m}^{-2}\right)\end{array}$ \\
\hline $\mathrm{U} 2_{00}$ & $27 \pm 3$ & 3 \\
$\mathrm{D} 1_{00}$ & $21 \pm 20$ & 5 \\
$\mathrm{D} 2_{00}$ & $18 \pm 7$ & 10 \\
$\mathrm{D} 3_{00}$ & $23 \pm 7$ & 4 \\
$\mathrm{D} 4_{00}$ & $18 \pm 3$ & 8 \\
\hline
\end{tabular}


Table 3. Ash-free dry mass (AFDM $\pm \mathrm{SE}$ ), bacterial densities, $\mathrm{NH}_{4}{ }^{+}$-oxidising and faecal coliforms recorded on epilithic biofilms collected in 2001. The recorded values of nitrification (mean of light and dark values) and denitrification activities are given for the samples $\mathrm{U} 1_{01}, \mathrm{D} 2_{01}$ and $\mathrm{D} 3_{01}$. na: not available

\begin{tabular}{|c|c|c|c|c|c|c|}
\hline Site & $\begin{array}{l}\text { AFDM } \\
\left(\mathrm{g} \mathrm{m}^{-2}\right)\end{array}$ & $\begin{array}{c}\text { Bacterial } \\
\text { densities } \\
\left(10^{12} \text { cells } \mathrm{m}^{-2}\right)\end{array}$ & $\begin{array}{c}\mathrm{NH}_{4}^{+} \text {-oxidising } \\
\text { bacteria } \\
\left(10^{9} \mathrm{MPN} \mathrm{m}^{-2}\right)\end{array}$ & $\begin{array}{c}\text { Faecal } \\
\text { coliforms } \\
\left(10^{6} \mathrm{CFU} \mathrm{m}^{-2}\right)\end{array}$ & $\begin{array}{l}\text { Nitrification } \\
\text { rates } \\
\left(\mathrm{mg} \mathrm{N} \mathrm{m}^{-2} \mathrm{~h}^{-1}\right)\end{array}$ & $\begin{array}{c}\text { Denitrification } \\
\text { rates } \\
\left(\mathrm{mg} \mathrm{N} \mathrm{m}^{-2} \mathrm{~h}^{-1}\right)\end{array}$ \\
\hline $\mathrm{U} 1_{01}$ & $16 \pm 2$ & 5 & 418 & 2 & 3.6 & 0.3 \\
\hline $\mathrm{U} 2_{01}$ & $15 \pm 4$ & 11 & 184 & 9 & na & na \\
\hline $\mathrm{D} 1_{01}$ & $12 \pm 3$ & 4 & 145 & 6 & na & na \\
\hline $\mathrm{D} 2_{01}$ & $10 \pm 2$ & 4 & 58 & 8 & 3.9 & 1.1 \\
\hline D3 01 & $13 \pm 10$ & 3 & 6 & 1 & 3.1 & 0.4 \\
\hline $\mathrm{D} 4_{01}$ & $10 \pm 3$ & 3 & 8 & 6 & na & na \\
\hline
\end{tabular}

(Table 2) and from 10 to $16 \mathrm{~g} \mathrm{~m}^{-2}$ in 2001 (Table 3). Bacterial densities were similar, ranging from 3 to $11 \times$ $10^{12}$ cells $\mathrm{m}^{-2}$ for both years.

In 2001 (Table 3), high MPN counts of $\mathrm{NH}_{4}{ }^{+}$-oxidising bacteria were found $\left(>8 \times 10^{9} \mathrm{MPN} \mathrm{m}^{-2}\right)$, and faecal coliforms densities remained rather stable (between 1 and $9 \times 10^{6} \mathrm{CFU} \mathrm{m}^{-2}$ ) along the longitudinal transect.

The values measured for the nitrification rates in light and dark conditions (about $3.6 \mathrm{mg} \mathrm{N} \mathrm{m}^{-2} \mathrm{~h}^{-1}$ ) were similar for all of the samples. Denitrification rates in dark conditions ranged from 0.3 to $1.1 \mathrm{mg} \mathrm{N} \mathrm{m}^{-2} \mathrm{~h}^{-1}$ (Table 3).

\section{DGGE analysis}

Reproducibility

Reproducibility between the different phases of the process was assessed (extraction, amplification and DGGE) and gave respectively similitude values of 97 , 97 and $90 \%$. Reproducibility of the sampling phase was assessed by comparing 3 replicates of sampling for 3 samples. For the 3 tested samples, similar patterns were obtained for the sampling replicates (Fig. 1). The percentage of similitude for these replicates, calculated from the binary matrix using the distance of Jaccard, ranged from 84 to $92 \%$.

\section{Application of DGGE on natural samples}

Seventy-four different bands were detected for the 11 samples collected in 2000 and 2001 (Fig. 2), and the number of bands per samples varied from 34 to 45 in each year. For the samples taken in 2000, 61 bands were detected; 19 of them were present in all of the 5 samples, and 9 in only 1 sample, thus being specific of these samples. In 2001, 62 different bands were detected; 17 were present in the 6 samples, and 9 in only 1 sample.
In all cases (419), the bands exhibited relative intensities lower than $10 \%$; 28 bands had intensities lower than $1 \%$ and most bands (255/419) showed intensities ranging from 1 to $3 \%$. However, for each sample, 21 to 28 bands (corresponding to $63 \%$ of the detected bands) accounted for about $80 \%$ of the total intensity of a lane.

The relative intensities of the bands were used to calculate diversity indices (Fig. 2). Similar values were found between up- and downstream samples; the mean values are about 0.034 and 5.06 for the Simpson and Shannon indices respectively.

The range of similitude values was very similar between years 2000 and 2001 (45 to 82 and 37 to $81 \%$ respectively).

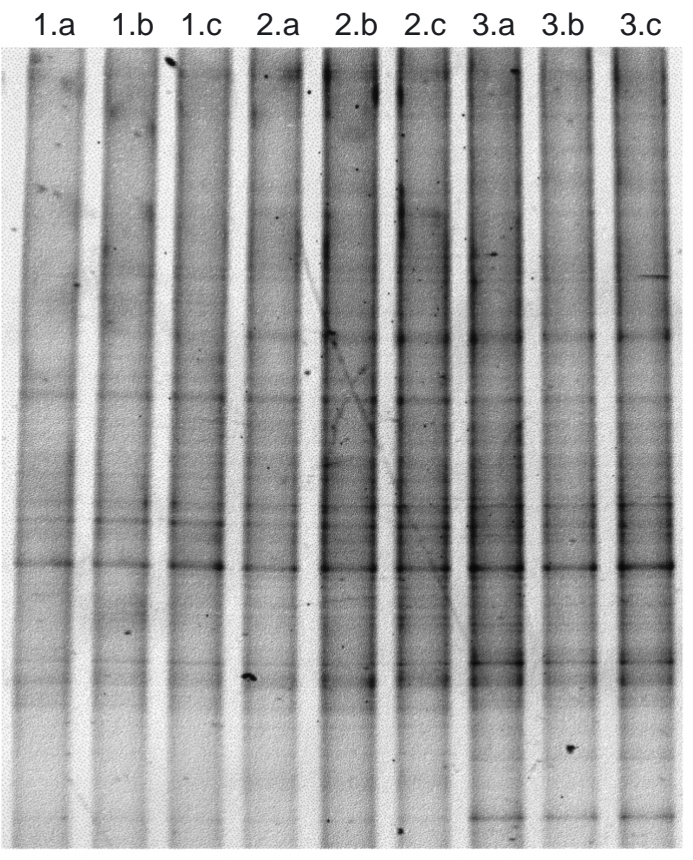

Fig. 1. Negative image of the DGGE gel obtained for the triplicates $(a, b$ and $c)$ of sampling. The 3 samples $(1,2$ and 3$)$ were collected at Site D2 in July 2000 
$\begin{array}{lllllllllllll}\mathrm{U} 2_{00} & \mathrm{D} 1_{00} & \mathrm{D} 2_{00} & \mathrm{D} 3_{00} & \mathrm{D} 4_{00} & \mathrm{U} 1_{01} & \mathrm{U} 2_{01} & \mathrm{D} 1_{01} & \mathrm{D} 2_{01} & \mathrm{D} 3_{01} & \mathrm{D} 4_{01}\end{array}$

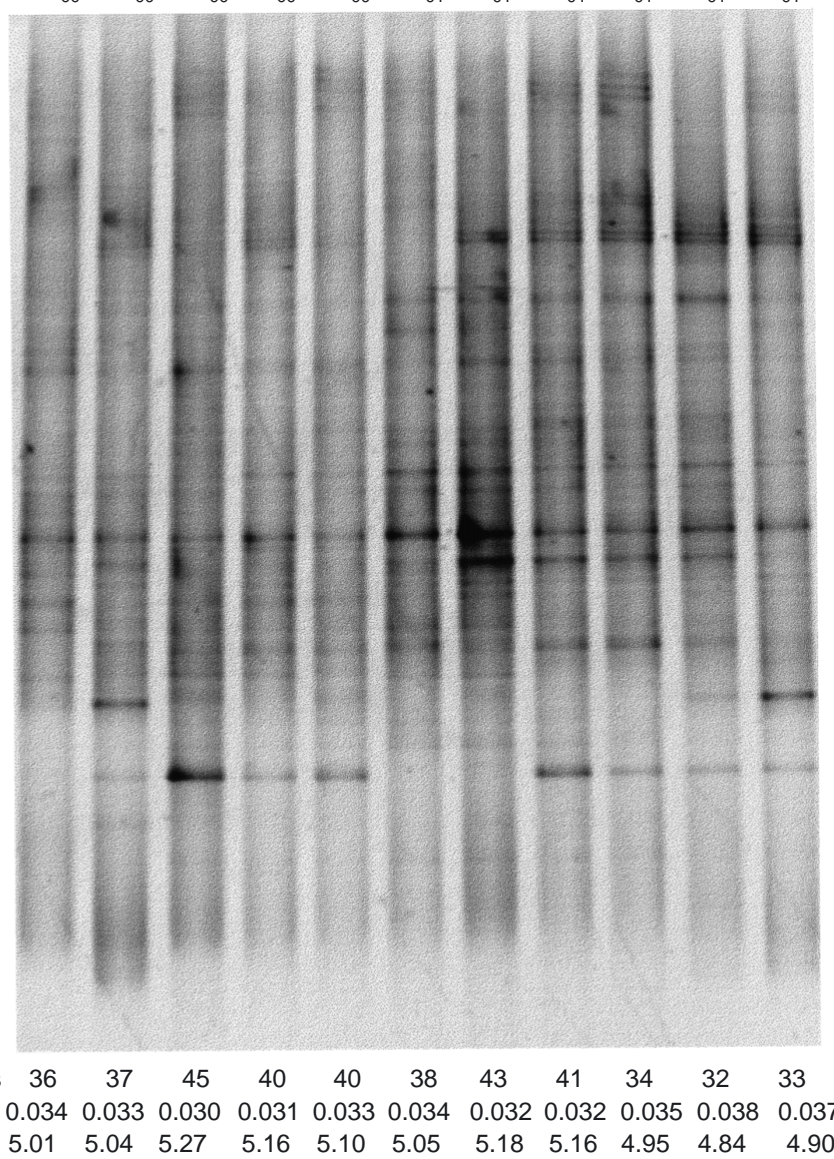

Fig. 2. Negative image of the DGGE gel for biofilm samples taken in 2000 and 2001 at the different sites of the river Garonne. Sample labels are explained in 'Materials and methods'

Taking into account that no samples were collected from Site U1 in 2000, the 2 dendrograms are very similar (Fig. 3a,b). In 2000, U2 $2_{00}$ can be separated from a cluster of the downstream samples (47\% similarity), while up- and downstream sample clusters can be separated in 2001 (41\% similarity). Moreover, a similar pattern in downstream sample clustering is observed in both 2000 and 2001.

\section{DISCUSSION}

\section{Methodological details}

In the present work, a relationship between recorded trends in epilithic bacterial responses and bacterial diversity was checked using PCR-DGGE. Applied to the study of unknown natural communities, fingerprints of a $16 \mathrm{~S}$ rDNA region provide infor- mation on the dominant ribotypes of the community (Muyzer \& Smalla 1998), while the top-to-bottom approach generally developed with FISH probing (Amann et al. 1995) often targets higher taxonomic levels. A more accurate description of the community structure is thus expected by fingerprinting (Araya et al. 2003) and in our case, a better discrimination between up- and downstream communities was aimed for.

PCR-DGGE is a method that has been widely used to study complex bacterial assemblages in natural environments (Muyzer 1999). However, sampling reproducibility appeared to be a factor that should be checked prior to monitoring the influence of point source anthropic discharges on spatial variability of epilithic bacterial communities. The samples that we intended to compare were processed at the same time (PCR mix and amplification) and were loaded in the same gel because the reproducibility between DGGE gels has been questioned (Moeseneder et al. 1999). As compared to similitude values calculated for sampling replicates (84 to $92 \%$ ), the range of similitude values obtained for samples from different sites (82 to $37 \%$ ) allows us to conclude that the differences observed between banding patterns can be related to sample characteristics.

We found that up- and downstream community patterns differentiate, while total bacterial densities, $\mathrm{NH}_{4}{ }^{+}$-oxidising bacteria and faecal coliforms densities, nitrification and denitrification rates were relatively homogeneous over the river reach. The same

100 30

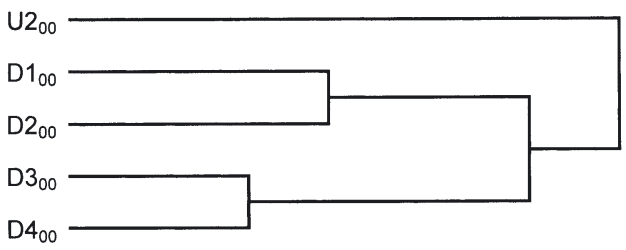

a

100 30

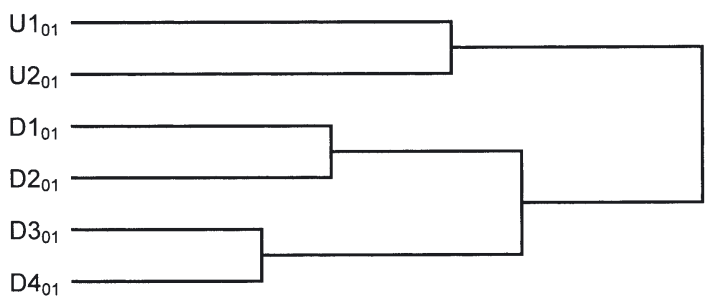

b

Fig. 3. UPGMA Jaccard distances dendrogram generated from the DGGE profiles of the biofilm samples collected (a) in 2000 and (b) in 2001 in the river Garonne 
kind of results has been found with benthic algal communities where water nutrient concentrations did not modify quantitative community descriptors, but affected the algal community structure instead (Stelzer \& Lamberti 2001, Griffith et al. 2002). Thus, it can be suspected that changes detected in the DGGE fingerprinting would be caused by changes in the algal community since the PCR primers used are known to amplify plastidial DNA (Schauer et al. 2000). However, when analysing bacterial diversity of epilithic biofilms by the cloning technique, $\mathrm{O}^{\prime}$ Sullivan et al. (2002) did not detect the presence of any sequences belonging to plastidial DNA using primers that proved to amplify plastidial 16S rDNA (Marchesi et al. 1998). The DGGE patterns obtained should thus be considered to reflect the bacterial community.

\section{Global diversity analysis}

As an estimate of bacterial richness, a higher number of bands or operational taxonomic units (OTUs) was found (38 bands on average per sample) compared to those reported for similar assemblages using the same fingerprinting method: 7 to 24 OTUs were found for epilithic biofilms grown in mesocosms (Jackson et al. 2001) and about 20 OTUs for epilithic biofilm grown on artificial substrata in a river (Araya et al. 2003). However, the highest richness recorded in this study may come from the origin of samples, i.e. pebbles in a natural system, suggesting that the actual epilithic bacterial diversity may be distorted by using artificial substrata as stated for algae by Cattaneo \& Amireault (1992).

The use of band relative intensity to calculate diversity indices is controversial, but Nübel et al. (1999) provided some evidence that comparable diversity indices were found between values derived from PCR-DGGE and morphotypes. In the studied set, calculated diversity indices (Shannon and Simpson) compared with values reported for diversified and balanced bacterial communities (Nübel et al. 1999, Schauer et al. 2000). Moreover, comparable values calculated for up- and downstream sites highlight bacterial communities' ability to remain diversified even in the presence of anthropic disturbances.

\section{Influence of anthropic discharges}

In the present study, epilithic biomass descriptors show equivalent values over the studied reach conflicting with previous findings (Teissier et al. 2002) where enhanced epilithic biomass was recorded downstream of a great centre. Obviously, these differences may depend on whether sampling occurs closely after a high-flow period (Teissier et al. 2002) or after a long period of low and stable flow (this study). During the accrual phase that follows the flood, enhanced epilithic biomass may occur downstream of anthropic discharges due to the stimulation of the accrual rate by trophic inputs (Biggs 1996). Conversely, after a long low-flow period, biomass may have reached stability (stationary phase) over the whole river section. Epilithic biomass is known to control bacterial densities (Sobczak 1996), activities (Teissier et al. 2002) and diversity (Jackson et al. 2001). Therefore, biomass stability over the studied section might explain why no differences were found between up- and downstream bacterial densities (total and $\mathrm{NH}_{4}{ }^{+}$-oxidising bacteria), nitrification and denitrification rates.

If epilithic biomass roughly describes biofilm maturation stage (Lock 1993), then the accordance between homogeneous biomass and the important number of ubiquitous taxa (50 taxa among 74) agrees with the diversity model proposed by Jackson et al. (2001).

Ubiquity of bacterial populations has already been mentioned in the literature for microbial assemblages (Gillan et al. 1998, Brümmer et al. 2000, Schauer et al. 2000) and is supposed to be responsible for the maintenance of stability in systems (Lindström 1998). For instance, in our case, the maintenance of activity rates such as nitrification and denitrification may be due to this stability. This may be emphasised in biofilm assemblages that represents an individualised community partly preserved from conditions prevailing in the overlying water (Costerton 2000).

On the other hand, for both years, indicating the same trends from one year to the next, $1 / 3(24 / 74)$ of the detected taxa discriminates between $(<45 \%$ similarity $)$ up- and downstream biofilms. As known for most animal and vegetal communities, bands discriminating between up- and downstream communities may behave as bio-indicative taxa of changes in water quality up- and downstream of the urban centre. This suggests that epilithic bacterial communities are not completely governed by interactions between organisms and resources within the assemblage, but also react to environmental fluctuations.

Acknowledgements. This work was partly supported by GIS ECOBAG (Groupement d'Intérêt Scientifique-Ecologie et Economie du Bassin Adour Garonne) and by a PhD fellowship from the French Ministère de la Recherche et de la Technologie to E.L. We are grateful to Dr. J.-F. Dumestre for valuable discussions about molecular techniques and to C. Mur and D. Dalger for the water quality analysis. We thank the 3 anonymous referees whose comments allowed us to improve the manuscript. 


\section{LITERATURE CITED}

Amann I, Ludwig W, Schleifer KH (1995) In situ identification of micro-organisms by whole cell hybridization with rRNA-targeted nucleic acid probes. In: Akkermans ADL, van Elsas JD, de Bruijn FJ (eds) Molecular microbial ecology manual. Kluwer Academic, Dordrecht, p 1-15

Araya R, Tani K, Takagi T, Yamaguchi N, Nasu M (2003) Bacterial activity and community composition in stream water and biofilm from an urban river determined by fluorescent in situ hybridization and DGGE analysis. FEMS Microbiol Ecol 43:111-119

Biggs BJF (1995) The contribution of flood disturbance, catchment geology and land use to the habitat template of periphyton in stream ecosystems. Freshw Biol 33:419-438

Biggs BJF (1996) Patterns in periphyton of streams. In: Stevenson RJ, Bothwell ML, Lowe RL (eds) Algal ecology-freshwater benthic ecosystems. Academic Press, San Diego, CA, p 31-56

Boulos L, Prévost M, Barbeau B, Coallier J, Desjardins R (1999) LIVE/DEAD BacLight: application of a new rapid staining method for direct enumeration of viable and total bacteria in drinking water. J Microbiol Methods 37: $77-86$

Brümmer IHM, Fehr W, Wagner-Döbler I (2000) Biofilm community structure in polluted rivers: abundance of dominant phylogenetic groups over a complete annual cycle. Appl Environ Microbiol 66:3078-3082

Casamayor E, Schafer H, Baneras L, Pedros-Alio P, Muyzer G (2000) Identification and spatio-temporal differences between microbial assemblages from two neighboring sulfurous lakes: comparison by microscopy and denaturing gradient gel electrophoresis. Appl Environ Microbiol 66:499-508

Cattaneo A, Amireault MC (1992) How artificial are artificial substrata for periphyton? J North Am Benthol Soc 11: $244-256$

Colwell RR, Grimes DJ (2000) Nonculturable microorganisms in the environment. ASM Press, Washington, DC

Costerton WJ (2000) Phenotypic plasticity in bacterial biofilms as it affects issues of viability and culturability. In: Colwell RR, Grimes DJ (eds) Non culturable microorganisms in the environment. ASM Press, Washington, DC, p 131-145

Dumestre JF, Casamayor E, Massana R, Pedros-Alio C (2001) Changes in bacterial and archaeal assemblages in an equatorial river induced by the water eutrophication of Petit Saut dam reservoir (French Guiana). Aquat Microb Ecol 26:209-221

Gillan DC, Speksnijder AGCL, Zwart G, De Ridder CD (1998) Genetic diversity of the biofilm covering Montacuta ferruginosa (Mollusca, Bivalvia) as evaluated by denaturing gel gradient electrophoresis analysis and cloning of PCRamplified gene fragment coding for 16S rRNA. Appl Environ Microbiol 64:3464-3472

Griffith MB, Hill BH, Herlihy AT, Kaufman PR (2002) Multivariate analysis of periphyton assemblages in relation to environmental gradients in Colorado Rocky Mountain streams. J Phycol 38:83-95

Jaccard P (1908) Nouvelles recherches sur la distribution florale. Bull Soc Vaudoise Sci Nat 44:223-270

Jackson CR, Churchill PF, Roden EE (2001) Successional changes in bacterial assemblage structure during epilithic biofilm development. Ecology 82:555-566

Lindström ES (1998) Bacterioplankton community composition in a boreal forest lake. FEMS Microbiol Ecol 27: 163-174
Lock MA (1993) Attached microbial communities in rivers. In: Ford TE (ed) Aquatic microbiology-an ecological approach. Blackwell Scientific Publications, Oxford, p 113-138

Marchesi JR, Sato T, Weightman AJ, Martin TA, Fry JC, Hiom SJ, Wade WG (1998) Design and evaluation of useful bacterium-specific PCR primers that amplify genes coding for 16S rRNA. Appl Environ Microbiol 64:795-799

Michener CD, Sokal RR (1957) A quantitative approach to a problem in classification. Evolution 11:130-162

Moeseneder MM, Arrieta JM, Muyzer G, Winter C, Herndl GJ (1999) Optimization of terminal-restriction fragment length polymorphism analysis for complex marine bacterioplankton communities and comparison with denaturing gradient gel electrophoresis. Appl Environ Microbiol 65: $3518-3525$

Montuelle B, Volat B, Torio-Fernandez MM, Navarro E (1996) Changes in Nitrobacter serotypes biodiversity in a river: impact of a wastewater treatment plant discharge. Water Res 30:1057-1064

Motomizu S, Wakimoto T, Toei K (1983) Spectrophotometric determination of phosphate in river waters with mobdylate and malachite green. Analyst 108:361-367

Murray AE, Hollibaugh JT, Orrego C (1996) Phylogenetic compositions of bacterioplankton from two California estuaries compared by denaturing gradient gel electrophoresis of 16S rDNA fragments. Appl Environ Microbiol 62:2676-2680

Muyzer G (1999) DGGE/TGGE a method for identifying genes from natural ecosystems. Curr Opin Microbiol 2: $317-322$

Muyzer G, Smalla K (1998) Application of denaturing gradient gel electrophoresis (DGGE) and temperature gradient gel electrophoresis (TGGE) in microbial ecology. Antonie Leeuwenhoek 73:127-141

Muyzer G, De Waal EC, Uitterlinden AG (1993) Profiling of complex microbial populations by denaturing gradient gel electrophoresis analysis of PCR-amplified genes coding for 16S rRNA. Appl Environ Microbiol 59:695-700

Muyzer G, Brinkhoff T, Nuber U, Santegoeds C, Schafer $H_{\text {, }}$ Wawer C (1997) Denaturing gradient gel electrophoresis (DGGE) in microbial ecology. In: Akkermans ADL, van Elsas JD, de Bruijn FJ (eds) Molecular microbial ecology manual. Kluwer Academic, Dordrecht, p 1-27

Nübel U, Garcia-Pichel F, Kuhl M, Muyzer G (1999) Quantifying microbial diversity: morphotypes, 16S rRNA genes, and carotenoids of oxygenic phototrophs in microbial mats. Appl Environ Microbiol 65:422-430

O'Sullivan LA, Weightman AJ, Fry JC (2002) New degenerate Cytophaga-Flexibacter-Bacteroides specific 16S ribosomal DNA-targeted oligonucleotide probes reveal high bacterial diversity in river Taff epilithon. Appl Environ Microbiol 68:201-210

Øvreås L, Forney L, Daae FL, Torsvik V (1997) Distribution of bacterioplankton in meromictic lake Saelenvannet as determined by denaturing gradient gel electrophoresis of PCR-amplified gene fragments coding for 16S rRNA. Appl Environ Microbiol 63:3367-3373

Peterson CG (1996) Response of benthic algal communities to natural physical disturbance. In: Stevenson RJ, Bothwell ML, Lowe RL (eds) Algal ecology - freshwater benthic ecosystems. Academic Press, San Diego, CA, p 57-72

Porter KG, Feig YS (1980) The use of DAPI for identifying and counting aquatic microflora. Limnol Oceanogr 25:943-948

Rodier J (1996) L'analyse de l'eau-eaux naturelles, eaux résiduaires, eau de mer. Dunod, Paris

Schauer M, Massana R, Pedros-Alio C (2000) Spatial differ- 
ences in bacterioplankton composition along the Catalan coast (NW Mediterranean) assessed by molecular fingerprinting. FEMS Microbiol Ecol 33:51-59

Schmidt EL, Belser LW (1994) Autotrophic nitrifying bacteria. In: Bigham JM (ed) Methods of soil analysis, Vol 5. Part 2. Microbiological and biochemical properties. SSSA Book Series, Madison, p 159-177

Shannon C, Weaver W (1963) The mathematical theory of communication, Vol 3. Urbana University of Illinois Press, Chicago

Simpson EH (1949) Measurement of diversity. Nature 163:688 Sobczak WV (1996) Epilithic bacterial responses to variations in algal biomass and labile dissolved organic carbon

Editorial responsibility: Karel Šimek, České Budéjovice, Czech Republic during biofilm colonization. J North Am Benthol Soc 15: 143-154

Stelzer RS, Lamberti GA (2001) Effects of N:P ratio and total nutrient concentration on stream periphyton community structure, biomass and elemental composition. Limnol Oceanogr 46:356-367

Teissier S, Torre M (2002) Simultaneous assessment of nitrification and denitrification on freshwater epilithic biofilms by acetylene block method. Water Res 36:3803-3811

Teissier S, Garabétian F, Torre M, Dalger D, Labroue L (2002) Impact of an urban centre on the nitrogen cycle processes of epilithic biofilms during a summer low water period. River Res Appl 18:21-30

Submitted: September 10, 2002; Accepted: September 2, 2003 Proofs received from author(s): October 30, 2003 